\title{
PARTIAL PURIFICATION OF GLUCOSE-6-PHOSPHATE DEHYDROGENASE BY AQUEOUS TWO-PHASE POLY(ETHYLENEGLYCOL)/PHOSPHATE SYSTEMS
}

\author{
Marcela Zanella Ribeiro ${ }^{1}$; Daniel Pereira Silva ${ }^{1,2 *}$; Michele Vitolo ${ }^{1}$; Inês Conceição Roberto ${ }^{3}$; Adalberto Pessoa-Jr ${ }^{1}$ \\ ${ }^{1}$ Biochemical-Pharmaceutical Technology Dept. / School of Pharmaceutical Sciences, University of São Paulo, São Paulo, SP, \\ Brazil; ${ }^{2}$ Institute for Biotechnology and Bioengineering, Centre for Biological Engineering, Universidade do Minho, Campus de \\ Gualtar, Braga, Portugal; ${ }^{3}$ Biotechnology Department / School of Engineering of Lorena, University of São Paulo, Lorena, SP, Brazil
}

Submitted: June 19, 2006; Returned to authors for corrections: August 17, 2006; Approved: January 18, 2007.

\begin{abstract}
Glucose-6-phosphate dehydrogenase (G6PDH) is an important enzyme used in biochemical and medical studies and in several analytical methods that have industrial and commercial application. This work evaluated the extraction of G6PDH in aqueous two-phase system (ATPS) of poly(ethyleneglycol) (PEG)/phosphate buffer, using as enzyme source a medium prepared through commercial baker's yeast disruption. Firstly, the effects of PEG molar mass on the enzyme partition and of homogenization and rest on the system equilibrium were investigated. Afterwards, several ATPS were prepared using statistical analysis ( $2^{2}$ factorial design). The results, including kinetic and thermodynamic parameters for the G6PDH activity, showed partial purification of this enzyme in ATPS composed of 17.5\% (w/w) PEG400 and 15.0\% (w/w) phosphate. A high enzymatic recovery value (97.7\%), a high partition coefficient (351), and an acceptable purification factor (2.28 times higher than in cell homogenate) were attained from the top phase. So, it was possible to attain an effective enzyme pre-purification by separating some contaminants with a simple method such as liquid-liquid extraction in aqueous two-phase systems (ATPS).
\end{abstract}

Key words: aqueous two-phase systems, glucose-6-phosphate dehydrogenase, liquid-liquid extraction, Saccharomyces cerevisiae

\section{INTRODUCTION}

Glucose-6-phosphate dehydrogenase (G6PDH, EC 1.1.1.49) is the key enzyme of the pentose phosphate pathway in carbohydrate metabolism. This enzyme plays an important role in various cell functions, being largely used either as a marker for enzyme immunoassays or as a reagent in many enzymatic assays, including those for determining hexokinase and creatine kinase activities, ATP and hexose concentrations and the amount of sugar illegally added to wine and fruit juices $(3,28)$.

Although G6PDH can be found in almost every animal tissue and in several microbial species, in Brazil, the use of Saccharomyces cerevisiae as a source of this enzyme and other products (15) is practical owing to the large experience of the Brazilian chemists in handling this strain in industrial plants. Besides, coupling the yeast processing with the ethanol production should probably have a positive effect on the profits of the distilleries (25). However, production of G6PDH can only be viable if large quantities of this enzyme are available at competitive prices. The development of techniques for the separation and purification of enzymes has been an indispensable prerequisite for many of the advancements in the biotechnological industry $(2,13,27)$.

According to Diamond and Hsu (12), 50-90\% of the production costs of biological products are determined by the purification strategy. Purification is troublesome because of the system complexity, and of the need to retain biological activity. Aqueous two-phase systems (ATPS) are liquid-liquid extraction processes widely used for the extraction and purification of many biological products. Their technical simplicity, easy operation, and scaleup makes them very attractive for industrial applications $(7,11,22,23)$. Moreover, ATPS such as Polyethyleneglycol (PEG)/

*Corresponding Author. Mailing address: Universidade do Minho, Departamento de Engenharia Biológica, Campus de Gualtar, 4710-057. Braga, Portugal. Fax: +351253678986. E-mail: silvadp@hotmail.com ou silvadp@deb.uminho.pt 
Phosphate, PEG/Citrate and PEG/Sulfate are adequate for continuous large-scale purification of biological origin materials and allow the use of traditional liquid-liquid extraction equipment (8-10,21).

The systems are formed from the mixture of aqueous solutions of two polymers or a polymer and an electrolyte solution. With the concentration of each component of the system in one of the phases (top or bottom) there is partition of biomolecules such as proteins, cells, cell particles or nucleic acids. To achieve a significant extraction, the target product has to be preferentially partitioned in favor of one phase, whereas the interfering substances (other biomolecules) should be partitioned to other phase. It is important to remember that higher water content in both phases avoids protein denaturation. Differences in enzyme partitioning can be ascribed to the interaction of the factors or mechanisms inherent in the system itself (such as choice of system components, polymer molar weight, concentration of polymers and salts, ionic strength, and $\mathrm{pH}$ values) with those of the target protein (such as hydrophobicity, charge, and molecular weight) $(24,26)$.

In practice, the simplicity of the extraction in ATPS is only apparent. As there are many factors that influence the partition and purification of proteins, this technique requires further experimentation to find an adequate system for each particular situation. For this reason, the aim of this work was to evaluate the purification of G6PDH produced by $S$. cerevisiae in aqueous PEG/phosphate systems.

\section{MATERIALS AND METHODS}

Chemicals: PEGs with molar masses of 300, 400, 1500 and $4000 \mathrm{~g} / \mathrm{mol}$ were purchased from Labsynth (São Paulo, BR), and with molar masses of 600 and $1000 \mathrm{~g} / \mathrm{mol}$ were purchased from Merck (Darmstadt, FRG). Glucose-6-phosphate dehydrogenase (G6PDH), nicotinamide adenine dinucleotide phosphate (NADP), and glucose-6-phosphate (G6P), utilized in the enzymatic analysis were obtained from Sigma Chemical (St. Louis, USA). All the other reagents were of analytical grade.

Cell Homogenate: The solution containing disrupted cells (denominated cell homogenate) was prepared by disrupting the commercial baker's yeast (S. cerevisiae), in a cell disruption camera with glass beads (diameter $=0.5 \mathrm{~mm}$ ). For this purpose, $45 \mathrm{~g}$ of wet cell cake previously washed with solution buffer (Tris- $\mathrm{HCl} 50 \mathrm{mM}$ ) and later suspended in $50 \mathrm{ml}$ of disruption solution (composed of phenylmethylsulfonyl fluoride PMSF $1 \mathrm{mM}$; $\beta$-mercaptoethanol $10 \mathrm{mM}$; ethylenediaminetetraacetic acid EDTA $0.2 \mathrm{mM}$; aminocaproic acid $2 \mathrm{mM}$; and buffer solution of Tris- $\mathrm{HCl} 50 \mathrm{mM}$ with $\mathrm{MgCl}_{2} 5 \mathrm{mM}$; $\mathrm{pH} 7.5$ ) was mixed with glass beads in the volumetric proportion of 1:1 (at a temperature below $10^{\circ} \mathrm{C}$ ). After disruption, cell debris and glass beads were removed by filtration. The cell homogenate (cell debris with disruption solution), stored at $-20^{\circ} \mathrm{C}$, was centrifuged at $2880 \mathrm{~g}$ for $10 \mathrm{~min}$ before each extraction in ATPS, and the supernatant was collected with G6PDH and other proteins.

Aqueous Two-Phase Systems: Aqueous two-phase systems were prepared with different PEGs $(300,400,600,1000$ and $1500 \mathrm{~g} /$ $\mathrm{mol}$ ) and phosphate using two stock solutions: $50 \%(\mathrm{w} / \mathrm{w}) \mathrm{PEG}$ and $40 \%$ (w/w) phosphate (mixture of $\mathrm{NaH}_{2} \mathrm{PO}_{4}$ and $\mathrm{K}_{2} \mathrm{HPO}_{4}$ ). In graduated centrifuge tubes $(15 \mathrm{ml}), 2.0 \mathrm{~g}$ of medium containing the target enzyme (cell homogenate) was mixed with the stock solutions (PEG and phosphate). Deionized water was then added to the mixture in order to adjust the final concentration of the components to the desired levels $(10 \mathrm{~g})$, whereas the $\mathrm{pH}$ values of the systems in the experiments were the same of those of the mixed phosphate buffer stock solution. For partitioning experiments, after ensuring partition equilibrium through homogenization, the phases were separated by centrifugation and the samples were withdrawn for analysis.

Partitioning Experiments: The effect of PEG molar mass on the partition coefficient of the G6PDH, the influence of the way of homogenizing the system on the interface volume and the extractions of G6PDH using statistical analysis were evaluated in partitioning experiments conducted in duplicate:

- Effect of PEG molar mass on the partition coefficient: The effect of PEG molar mass (MMPEG) on the partition coefficient $(\mathrm{K})$ of the target enzyme (G6PDH) was evaluated using systems formed with 20\% (w/w) PEG and 15\% (w/w) phosphate solution at $\mathrm{pH} 7.5$ and $4^{\circ} \mathrm{C}$. These ATPS were homogenized by agitation in vortex during 1 min followed by centrifugation at $2500 \mathrm{~g}(15 \mathrm{~min})$ for separation of the phases, at a temperature below $10^{\circ} \mathrm{C}$. Immediately after this procedure, the volumes of the phases (top, interface and bottom) were observed with samples withdrawn for analysis.

- Effect of the way of homogenizing the system on the interface volume: The effect of the way of homogenizing the system on the interface volume was evaluated under the same conditions previously described, using only PEGs of 400 and $1500 \mathrm{~g} / \mathrm{mol}$. This was investigated using agitation in vortex for $1 \mathrm{~min}$ or rotation ( $8 \mathrm{rpm}$ ) for $20 \mathrm{~min}$. Both conditions were followed by centrifugation at $2500 \mathrm{~g}(15 \mathrm{~min})$ for the phases separation, at a temperature below $10^{\circ} \mathrm{C}$.

- Effect of PEG and phosphate concentrations on the G6PDH partition: Effects of PEG (400 or $1500 \mathrm{~g} / \mathrm{mol}$ ) and phosphate concentrations (\%PEG and \%phosphate) on the G6PDH partitions in ATPS were evaluated. The levels of the variables used for the extraction (Table 1) were in accordance with the method of experimental design proposed by Box et al. (4). The results of the experiments, which were based on a $2^{2}$ factorial design with 2 repetitions at the central point, were statistically analyzed by using the program Statgraphics Plus 6.0. 
Table 1. Levels of the variables PEG (400 or $1500 \mathrm{~g} / \mathrm{mol}$ ) and phosphate concentrations utilized in the $2^{2}$ factorial design.

\begin{tabular}{lccc}
\hline \multicolumn{1}{c}{ Variable } & $\begin{array}{c}\text { Maximum level } \\
(+)\end{array}$ & $\begin{array}{c}\text { Central level } \\
(0)\end{array}$ & $\begin{array}{c}\text { Minimum level } \\
(-)\end{array}$ \\
\hline \%PEG & 20.0 & 17.5 & 15.0 \\
\%phosphate & 17.5 & 15.0 & 12.5 \\
\hline
\end{tabular}

\section{Analytical Methodology}

G6PDH activity was measured spectrophotometrically at $30^{\circ} \mathrm{C}$ by following the rate of $\mathrm{NADP}^{+}$reduction at $340 \mathrm{~nm}$ in a coupled enzyme assay system, according to the method described by Bergmeyer et al. (3). The assay mixture consisted of $50 \mathrm{mM}$ Tris- $\mathrm{HCl}(\mathrm{pH} 7.5), 5 \mathrm{mM} \mathrm{MgCl}, 0.5 \mathrm{mM} \mathrm{NADP}^{+}$and $10 \mathrm{mM}$ glucose-6-phosphate. One unit (U) of enzyme activity was defined as the amount of enzyme required to form $1.0 \mathrm{mmol}$ of NADPH/min with the excess substrate under the experimental conditions employed.

The partition coefficient of the enzyme $(\mathrm{K})$ was defined as the ratio between the enzyme activities in the top and bottom phases. The total concentration of proteins was determined according to the Bradford's method (6), using bovine serum albumin (BSA) as standard. Selectivity (S) was calculated as the ratio between the partition coefficient of G6PDH and the partition coefficient of the total proteins. The increase in purity (Pur) was determined from the ratio between the specific activities of the enzyme $\left[\mathrm{U} / \mathrm{mg}_{\text {Prot }}\right]$ before and after the extraction. The extraction yield (\%R) was obtained from the ratio between the total proteins [mg] or total activity of the enzyme [U] in the phases obtained after and before the extraction, using the volume of each phase.

The kinetic and thermodynamic parameters of G6PDH were evaluated using pure enzyme and cell homogenate with samples taken before and after the extraction in ATPS prepared with $17.5 \%(\mathrm{w} / \mathrm{w})$ PEG400 and 15\% (w/w) phosphate. Kinetic parameters, such as Michaelis/Menten constant $\left(\mathrm{K}_{\mathrm{M}}\right)$ and maximum velocity of enzymatic reaction $\left(\mathrm{V}_{\max }\right)$, were determined by Lineweaver-Buk method (18) using the enzymatic activity curve of G6PDH as a function of different substrate concentrations (5.0 to $15000 \mu \mathrm{M})$. Thermodynamic parameters such as activation energy (Ea), Gibbs free energy $(\Delta \mathrm{G})$, enthalpy $(\Delta \mathrm{H})$ and entropy $(\Delta \mathrm{S})$, were also determined by Arrhenius and Eyring equations (19) using enzymatic activity curve of G6PDH at different temperatures $\left(30\right.$ to $\left.90^{\circ} \mathrm{C}\right)$.

\section{RESULTS AND DISCUSSION}

\section{Effect of PEG molar mass on the G6PDH partition coefficient}

The effects of different PEG molar masses on the partition coefficient of G6PDH, and on total proteins after extraction in
ATPS, as well as the enzymatic activities measured in the different phases of the systems are shown in Table 2. As can be observed, in smaller MMPEG $(300,400$ and $600 \mathrm{~g} / \mathrm{mol})$ there was a tendency for G6PDH to stay in the top phase (PEG phase). When higher MMPEG (1000 and $1500 \mathrm{~g} / \mathrm{mol}$ ) were used G6PDH stayed in larger amount in the bottom phase of the system, providing low $\mathrm{K}$ and suggesting a larger hydrophobicity of this enzyme since the higher hydrophobicity of the protein increases its tendency to migrate to the PEG-rich phase $(1,14,20)$. Moreover, like the salts, PEG competes with proteins for water and exerts the excluded volume effects (17).

Table 3 shows the volumes of the top, interface and bottom phases of the systems obtained after extraction in ATPS using different MMPEGs. As can be seen, extractions in PEG/ phosphate systems using cell homogenate presented cellular fragments occupying a large space between the top and bottom phases of ATPS, and the interface volumes increased with the increase in the MMPEG used for the extractions.

Table 2. Effects of different PEG molar masses on the partition coefficient of G6PDH after extraction by ATPS (20\% (w/w) PEG and $15 \%(\mathrm{w} / \mathrm{w})$ phosphate solution at $\mathrm{pH} 7.5$ and $\left.4^{\circ} \mathrm{C}\right)$ with homogenization occurring in vortex $(1 \mathrm{~min})$ followed by centrifugation $(2500 \mathrm{~g} / 15 \mathrm{~min})$.

\begin{tabular}{cccccc}
\hline MMPEG & $\begin{array}{c}\text { top } \\
\text { phase } \\
\text { activity } \\
(\mathrm{U} / \mathrm{ml})\end{array}$ & $\begin{array}{c}\text { interface } \\
\text { phase } \\
\text { activity } \\
(\mathrm{U} / \mathrm{ml})\end{array}$ & $\begin{array}{c}\text { bottom } \\
\text { phase } \\
\text { activity } \\
(\mathrm{U} / \mathrm{ml})\end{array}$ & $\begin{array}{c}\mathrm{K} \\
\text { G6PDH }\end{array}$ & $\begin{array}{c}\mathrm{K} \\
\text { Total } \\
\text { proteins }\end{array}$ \\
\hline 300 & 1.30 & 0.67 & 0.02 & 65.0 & 15.7 \\
400 & 1.95 & 0.24 & 0.00 & $\infty$ & $\infty$ \\
600 & 2.14 & 0.21 & 0.09 & 23.8 & 60.3 \\
1000 & 0.35 & 0.00 & 1.60 & 0.22 & 1.19 \\
1500 & 0.04 & 1.47 & 2.62 & 0.01 & 0.57 \\
\hline
\end{tabular}

Table 3. Effects of different PEG molar masses on the volume of the phases after extraction by ATPS (20\% (w/w) PEG and 15\% $(\mathrm{w} / \mathrm{w})$ phosphate solution at $\mathrm{pH} 7.5$ and $4^{\circ} \mathrm{C}$ ) with homogenization occurring in vortex $(1 \mathrm{~min})$ followed by centrifugation $(2500 \mathrm{~g} / 15 \mathrm{~min})$.

\begin{tabular}{cccc}
\hline MMPEG & $\begin{array}{c}\text { top phase } \\
\text { volume }(\mathrm{ml})\end{array}$ & $\begin{array}{c}\text { interface phase } \\
\text { volume }(\mathrm{ml})\end{array}$ & $\begin{array}{c}\text { bottom phase } \\
\text { volume }(\mathrm{ml})\end{array}$ \\
\hline 300 & 7.2 & 0.5 & 1.0 \\
400 & 5.6 & 1.9 & 0.9 \\
600 & 5.7 & 3.1 & 0.2 \\
1000 & 3.0 & 3.4 & 2.5 \\
1500 & 3.4 & 3.7 & 1.7 \\
\hline
\end{tabular}


According to Braas et al. (5) and Lebreton and Lyddiatt (16), this intermediate phase can be denominated or be considered as a third phase of the system (interface), harming not only the transfer of proteins to one of the phases, but also the partition coefficient of the target enzyme. For this reason, the equilibrium of PEG/phophate system caused by of the homogenization method during the partition process (agitation in vortex or rotation, and times of rest after extraction) was investigated in order to establish precise extraction conditions with small or no interface volume.

\section{Effect of the homogenization of the system}

Table 4 shows the variations in interface volume after the separation of the phases at different times of rest using PEGs 400 or $1500 \mathrm{~g} / \mathrm{mol}$, and homogenization with agitation in vortex ( $1 \mathrm{~min}$ ) or rotation $(8 \mathrm{rpm} / 20 \mathrm{~min})$. As can be observed, for the PEG1500 system agitated under vortex the interface volume increased more than for the PEGs 1500 and 400 systems agitated under rotation. For this reason, the subsequent extractions could only be performed with homogenization under rotation $(8 \mathrm{rpm} /$ $20 \mathrm{~min}$ ), which caused small variations in the interface volume of both the PEGs.

\section{Effects of PEG and phosphate concentrations on the G6PDH partition}

After evaluating the effect of PEG molar mass on the partition coefficient of G6PDH, and the equilibrium of the PEG/phosphate systems homogenized in different ways, experiments using statistical analysis ( $2^{2}$ factorial design) were conducted to verify the effects of the concentrations of PEG (400 and $1500 \mathrm{~g} / \mathrm{mol}$ ) and phosphate on the G6PDH partition. The conditions established for the factorial design and the results are shown in Table 5. The statistical analysis of these results employing analysis of variance and Student's $t$ test showed that the concentrations of PEG (400 and $1500 \mathrm{~g} / \mathrm{mol}$ ) and of phosphate,

Table 4. Effect of rest time on the interface volume obtained after centrifugation $(2500 \mathrm{~g} / 15 \mathrm{~min})$ of the systems $(20 \% \mathrm{w} / \mathrm{w}$ PEGs 400 or 1500 and $15 \%$ w/w phosphate) homogenized by vortex or rotation.

\begin{tabular}{ccccc}
\hline & \multicolumn{4}{c}{ Interface volume $(\mathrm{ml})$} \\
\cline { 2 - 5 } Time of rest & \multicolumn{2}{c}{ vortex $(1 \mathrm{~min})$} & \multicolumn{3}{c}{ rotation $(8 \mathrm{rpm} / 20 \mathrm{~min})$} \\
\cline { 2 - 5 }$(\mathrm{h})$ & PEG400 & PEG1500 & PEG400 & PEG1500 \\
\hline 0 & 1.8 & 6.1 & 1.8 & 1.0 \\
1 & 1.8 & 6.2 & 1.8 & 1.1 \\
3 & 1.4 & 6.5 & 1.4 & 1.3 \\
5 & 1.7 & 6.6 & 1.9 & 1.3 \\
7 & 1.9 & 6.8 & 1.8 & 1.4 \\
\hline
\end{tabular}

Table 5. Partition coefficient (K) of G6PDH in relation to PEG and phosphate concentrations, based on a factorial design, using $\mathrm{pH} 7.5,4^{\circ} \mathrm{C}$ and homogenization by rotation $(8 \mathrm{rpm} / 20$ $\mathrm{min}$ ) followed by centrifugation $(2500 \mathrm{~g} / 15 \mathrm{~min})$.

\begin{tabular}{ccccc}
\hline Experiments & \%PEG & \%phosphate & $\mathrm{K}$ & $\mathrm{K}$ \\
& & & PEG400 & PEG1500 \\
\hline 1 & $15.0(-)$ & $12.5(-)$ & $\mathrm{NS}^{\mathrm{a}}$ & 0.0035 \\
2 & $20.0(+)$ & $12.5(-)$ & 258 & 0.0030 \\
3 & $15.0(-)$ & $17.5(+)$ & 334 & 0.0075 \\
4 & $20.0(+)$ & $17.5(+)$ & 246 & 0.0022 \\
5 & $17.5(0)$ & $15.0(0)$ & 351 & 0.0040 \\
6 & $17.5(0)$ & $15.0(0)$ & 294 & 0.0035 \\
\hline
\end{tabular}

${ }^{\mathrm{a}} \mathrm{NS}=$ no phase separation.

as well as their interactions, were not significant variables in the extraction process at $90 \%$ confidence level.

However, by using the liquid-liquid extraction of G6PDH in ATPS with $17.5 \%(\mathrm{w} / \mathrm{w})$ PEG400 and $15.0 \%(\mathrm{w} / \mathrm{w})$ phosphate, a higher $\mathrm{K}$ value (experiment 5 , Table 5), with an increase in purity (Pur) in the top phase 2.28 times higher than in cell homogenate, and an enzymatic recovery of $97.7 \%$ could be obtained. The results show that with $17.5 \%(\mathrm{w} / \mathrm{w})$ PEG 400 and $15.0 \%$ (w/w) phosphate solution it is possible to attain an effective enzyme pre-purification separating some contaminants with a simple method such as liquid-liquid extraction in aqueous two-phase systems (ATPS).

\section{Evaluation of kinetic and thermodynamic parameters}

Kinetic and thermodynamic parameters of G6PDH, using pure enzyme and cell homogenate withdrawn before and after enzyme extraction in ATPS, were evaluated in order to verify possible alterations in the enzyme characteristics caused by the extraction (Table 6).

Table 6 shows a reduction in the values of the kinetic constant of the enzyme only after the extraction, indicating a possible inhibition effect of PEG400 on the G6PDH, since both PEG and enzyme are in the top phase of ATPS. This inhibition suggests an interaction between PEG and the enzyme during the formation of non-covalent connections (probably hydrogen bound) among the macromolecules. Table 6 also shows that the variation of free energy of the reaction at constant temperature and pressure was not significant (5\% level) for the purity degree of the enzyme. In other words, the specificity of G6PDH for G-6-P and NADP ${ }^{+}$ remained unaffected. Besides, an accentuated decrease in the values of Ea and $\Delta \mathrm{H}$ was observed for the homogenate when compared with pure G6PDH dissolved in buffer solution without contaminants. A smaller Ea could have been resulted from the fact that, in homogenate containing G-6-P or $\mathrm{NADP}^{+}$of endogenous origin, the intermediate compound of G6PDH would 
Table 6. Kinetic and thermodynamic parameters of G6PDH: pure enzyme from Sigma ${ }^{\circledR}$ and cell homogenate withdrawn before and after enzyme extraction in ATPS.

\begin{tabular}{cccc}
\hline Parameters & \multicolumn{3}{c}{ Enzyme } \\
\cline { 2 - 4 } & $\begin{array}{c}\text { pure } \\
\text { (Sigma) }\end{array}$ & $\begin{array}{c}\text { before } \\
\text { extraction } \\
\text { (homogenate) }\end{array}$ & $\begin{array}{c}\text { after } \\
\text { extraction } \\
\text { (homogenate) }\end{array}$ \\
\hline $\mathrm{K}_{\mathrm{M}}(\mathrm{mM})$ & 49.10 & 49.70 & 16.70 \\
$\mathrm{Vmax}(\mathrm{U} / \mathrm{ml})$ & 3.37 & 7.77 & 1.08 \\
$\Delta \mathrm{G}(\mathrm{kJ} / \mathrm{mol})$ & -11.49 & -11.19 & -11.75 \\
$\Delta \mathrm{H}\left(\mathrm{kJ} /{ }^{\circ} \mathrm{Kmol}\right)$ & 9.23 & 2.89 & 3.12 \\
$\Delta \mathrm{S}(\mathrm{kJ} / \mathrm{Kmol})$ & 0.037 & 0.046 & 0.049 \\
$\mathrm{Ea}\left(\mathrm{kJ} /{ }^{\circ} \mathrm{Kmol}\right)$ & 11.75 & 5.41 & 5.63 \\
\hline
\end{tabular}

pre-exist with one of the substrates. In this case, the system would need less energy to reach the transition state if the enzyme activity was measured in the standardized habitat reaction.

\section{CONCLUSIONS}

The extraction of proteins by the aqueous PEG/phosphate system with quite simple reagents and stages of process confirmed to be effective. Its use in the partial purification of proteins is also viable and gives good results. In this work a partial purification of glucose-6-phosphate dehydrogenase was possible using $17.5 \%$ (w/w) PEG 400 and 15\% (w/w) phosphate buffer at $\mathrm{pH} 7.5$ and $4^{\circ} \mathrm{C}$. A high enzymatic recovery value (97.7\%), a high partition coefficient (351), and an acceptable purification factor (2.28 times higher than in cell homogenate) were attained from the top phase.

\section{ACKNOWLEDGMENTS}

Marcela Z. Ribeiro acknowledges the fellowship from FAPESP (Fundação de Amparo à Pesquisa do Estado de São Paulo / Brasil). The authors acknowledge the financial support of FAPESP, CNPq (Conselho Nacional de Desenvolvimento Científico e Tecnológico / Brasil) and CAPES (Coordenação para Aperfeiçoamento do Ensino Superior / Brasil).

\section{RESUMO}

\section{Purificação parcial de glucose-6-fosfato desidrogenase por sistemas de duas fases aquosas poli (etilenoglicol)/fosfato}

Glicose-6-fosfato desidrogenase (G6PDH) é uma importante enzima usada em estudos bioquímicos e médicos, bem como em diversos métodos analíticos com aplicação comercial e industrial. Neste trabalho foi avaliado a extração da G6PDH em sistemas de duas fases aquosas (ATPS) constituídos por poli(etilenoglicol) (PEG)/tampão fosfato, usando como fonte de enzima um meio preparado por rompimento de leveduras de panificação comercial. Inicialmente foram investigados os efeitos da massa molar do PEG na partição da enzima e da homogeneização e repouso no equilíbrio do sistema. $\mathrm{Na}$ sequência, diversos ATPS foram preparados usando análise estatística (planejamento fatorial $2^{2}$ ). Os resultados, incluindo parâmetros cinéticos e termodinâmicos para a atividade da G6PDH, indicaram parcial purificação desta enzima em ATPS constituídos por 17,5\% (p/p) PEG400 e 15,0\% (p/p) fosfato. Um alto valor de recuperação enzimática $(97,7 \%)$, um alto coeficiente de partição (351), e um fator de purificação aceitável (2,28 vezes maior que em homogenato celular) foram obtidos na fase superior do sistema. Assim, foi possível alcançar uma prépurificação eficaz da enzima separando alguns contaminadores aplicando um método simples tal como a extração líquido-líquido em sistemas bifásicos (ATPS).

Palavras-chave: sistema de duas fases aquosas, glicose-6fosfato desidrogenase, extração líquido-líquido, Saccharomyces cerevisiae

\section{REFERENCES}

1. Albertsson, P.A. (1986). Partition of cell particles and macromolecules. Wiley-Interscience, New York.

2. Banik, R.M.; Santhiagu, A.; Kanari, B.; Sabarinath, C.; Upadhyay, S.N. (2003). Technological aspects of extractive fermentation using aqueous two-phase systems. World J. Microbiol. Biotechnol., 19(4), 337-348.

3. Bergmeyer, H.U.; Bergmeyer, J.; Grassl, M. (1983). Methods of Enzymatic Analysis v.2, Verlag Chemie, Weinheim.

4. Box, G.E.P.; Hunter, W.G.; Hunter, J.S. (1978). Statistics for Experimenters, Wiley-Interscience, New York.

5. Braas, G.M.F.; Walker S.G.; Lyddiatt, A. (2000). Recovery in aqueous two-phase systems of nanoparticulates applied as surrogate mimics for viral gene therapy vectors. J. Chromatogr. B Biomed. Sci. Appl., 743(1-2), 409-419.

6. Bradford, M.M. (1976). A rapid and sensitive method for the quantitation of microgram quantities of protein utilizing the principle of protein-dye binding. Analytical Biochemistry, 72, 248-254.

7. Chaves, A.C.; Silveira, E.; Bezerra, R.P.; Moreira, K.A.; LucenaSilva, N.L.C.; Abath, F.G.C.; Porto, A.L.F.; Cabral, J.M.S.; LimaFilho, J.L. (2002). Influence of partition parameters on a recombinant antigen of Schistosoma mansoni expressed on E. coli using poly(ethylene glycol)-hydroxypropyl starch aqueous two-phase system. World J. Microbiol. Biotechnol., 18(7), 645-648.

8. Coimbra, J.S.R.; Thommes, J.; Kula, M.R. (1994). Continuous separation of whey proteins with aqueous two-phase systems in a Graesser contactor. J. Chromatog. A, 668, 85-94.

9. Coimbra, J.S.R.; Thommes, J.; Meirelles, A.J.A.; Kula, M.R. (1995). Performance of a Graesser contactor in the continuous extraction of whey proteins: mixing, mass transfer and efficiency. Bioseparation, 5(5), 259-268.

10. Coimbra, J.S.R.; Mojola, F.; Meirelles, A.J.A. (1998). Dispersed phase hold-up in a perforated rotating disc contactor (PRDC) using aqueous two-phase systems. J. Chem. Eng. Jpn., 31(2), 277-280. 
11. Cortez, E.V.; Pessoa Jr., A.; Felipe, M.G.A.; Roberto, I.C.; Vitolo M. (2004). Liquid-liquid extraction of xylitol dehydrogenase from Candida guilliermondii homogenate by reversed micelles. $J$. Chromatogr. B Analyt. Technol. Biomed. Life Sci., 807(1), 55-60.

12. Diamond, A.D.; Hsu, J.T. (1992). Aqueous two-phase systems for biomolecule separation. Adv. Biochem. Eng. Biotechnol., 47, 89135.

13. Ferreira, L.F.P.; Taqueda, M.E.; Vitolo, M.; Converti, A.; Pessoa Jr., A. (2005). Liquid-liquid extraction of commercial glucose oxidase by reversed micelles. J. Biotechnol., 116(4), 411-416.

14. Forciniti, D.; Hall, C.K.; Kula, M.R. (1991). Protein Partitioning at the Isoelectric Point: Effect of Polymer Concentration and Polymer Molecular Weight. Biotechnol. Bioeng., 38, 986-994.

15. Godfrey, T.; West, S. (2001). Industrial Enzymology, MacMillan Press, London.

16. Lebreton, B.; Lyddiatt, A. (2000). Application of aqueous two-phase partition to the production of homogeneous preparations of fluorescently labelled human serum albumin. J. Chromatogr. B Biomed. Sci. Appl., 743(1-2), 263-269.

17. Lee, E.K.; Kim, W.S. (2003). Protein Crystallization for LargeScale Bioseparation. In: Hatti-kaul, R, Mattiasson, B. (eds). Isolation and Purification of Proteins. Marcel Dekker, New York, p. 277-320.

18. Lehninger, A.L.; Nelson, D.L.; Cox, M.M. (1993). Principles of Biochemistry. Worth Publishers, New York.

19. Owusu, R.K.; Makhzoum, A.; Knapp, J.S. (1992). Heat inactivation of lipase from psychrotrophic Pseudomonas fluorescens P38: Activation parameters and enzyme stability at low or ultra-high temperatures. Food Chem., 44(4), 261-268.

20. Pancera, S.M.; Silva, L.H.M.; Loh, W.; Itri, R.; Pessoa Jr, A.; Petri, D.F.S. (2002). The effect of poly(ethylene glycol) on the activity and structure of glucose-6-phosphate dehydrogenase in solution. Colloids Surf. B: Biointerfaces, 26, 291-300.

21. Porto, T.S.; Monteiro, T.I.R.; Moreira, K.A.; Lima-Filho, J.L.; Silva, M.P.C.; Porto, A.L.F.; Carneiro-da-Cunha, M.G. (2005). Liquid-liquid extraction of an extracellular alkaline protease from fermentation broth using aqueous two-phase and reversed micelles systems. World J. Microbiol. Biotechnol., 21(5), 655-659.

22. Rito-Palomares, M. (2004). Practical application of aqueous twophase partition to process development for the recovery of biological products J. Chromatogr. B Analyt. Technol. Biomed. Life Sci., 807(1), 3-11.

23. Schügerll, K.; Hubbuch, J. (2005). Integrated bioprocesses. Curr. Opin. Microbiol., 8(3), 294-300.

24. Schmidt, A.S.; Ventom A.M.; Asenjo J.A. (1994). Partitioning and purification of alpha-amylase in aqueous two-phase systems. Enzyme Microb. Technol., 16(2), 131-142.

25. Silva, D.P.; Pessoa Jr, A.; Roberto, I.C.; Vitolo, M. (2002). Effect of $\mathrm{k}_{\mathrm{L}} \mathrm{a}$ on the production of glucose-6-phosphate dehydrogenase from Saccharomyces cerevisiae grown by fermentation process. Appl. Biochem. Biotechnol., 98-100, 205-213.

26. Venancio, A.; Almeida C.; Teixeira, J.A. (1996). Enzyme purification with aqueous two-phase systems: comparison between systems composed of pure polymers and systems composed of crude polymers. J. Chromatog. B, 680(1-2), 131-136.

27. Xu, Y.; Vitolo, M.; Albuquerque, C.N.; Pessoa Jr, A. (2002). Affinit partitioning of glucose-6-phosphate dehydrogenase and hexokinase in aqueous two-phase systems with free triazine dye ligands. $J$. Chromatog. B, 780, 53-60.

28. Whitaker J.R. (1991). Enzymes in analytical chemistry. In: Fox, P.F (ed). Food Enzymology. Elsevier Applied Science, New York, p.287-308. 